\title{
Revisiting Interreligious Relationship and Minority Groups in Indonesia
}

\author{
Irawan \\ Fakultas Dakwah \\ IAIN Syaikh Abdurrahman Siddik Bangka Belitung \\ Bangka, Indonesia \\ irsyamsudin@ymail.com
}

\begin{abstract}
Indonesia is a democratic country. Every believer is free to worship according to their beliefs. But in fact, it is still found disharmonious relationship and violence acts between Islamic minority groups or other minority adherents and Islamic majority groups. Based on Setara Institute, there are still 201 violations (2017) and 208 (2016) in this country. Then, bom terrors to minorities groups still happen (On May 13, 2018 in Surabaya). This article aims to describe the meaning of interreligious relationship, the portrait of interreligious relationship in Indonesia, and how to foster tolerance and defend minority groups in the context of Indonesian Islam. This article is analyzed by using "the theory of interreligious relationship perspective". This paper concluded that: the first, to avoid religious conflict and violent acts, everyone must return to the motto Bhinneka Tunggal Ika (Unity in Diversity). The second, Islamic minority groups or minority religious adherents are not allowed to be oppressed by any other groups because of different belief. The violent acts are contrary to the 1945 Constitution and Pancasila. Everyone has right to live in the Unitary State of the Republic of Indonesia (NKRI). The third, imams, ulamas, and religious leaders can function to be deterrent in religion conflict and violent acts by doing dialogue or win-win solution while referring to Islamic traditions. This study is hoped to be researched and explored more comprehensive in the future in order harmonious religious life in Indonesia will be better.
\end{abstract}

Keywords: Interreligious relationship, minority groups, Islamic tradition, dialogue

Abstrak

Indonesia adalah suatu negara demokratis. Setiap umat yang beriman bebas untuk beribadah menurut keyakinan mereka. Namun, kenyataannya, masih dijumpai hubungan yang tidak harmonis dan tindakan-tindakan kekerasan antara kelompok-kelompok Islam minoritas atau penganut-penganut minoritas lainnya. Berdasarkan data Setara Institute, masih ada 201 tindakan kekerasan (2017) dan 208 (2016) di negara ini. Selanjutnya, terorteror bom terhadap kelompok-kelompok minoritas masih terjadi (13 Mei 2018 di Surabaya). Tulisan ini bertujuan untuk mendeskripsikan makna hubungan antaragama, potret hubungan antaragama di Indonesia, dan bagaimana menjaga toleransi dan melindungi kelompok-kelompok minoritas dalam konteks Islam Indonesia. Artikel ini dianalisa dengan menggunakan "the theory of interreligious relationship perspective". Tulisan ini menyimpulkan bahwa: Pertama, untuk menghindari konflik atas nama agama 
dan tindakan-tindakan kekerasan, setiap orang harus kembali kepada semboyan Bhinneka Tunggal Ika (Unity in Diversity). Kedua, kelompok-kelompok Islam minoritas atau para penganut agama minoritas tidak boleh ditindas oleh kelompok-kelompok lainnya hanya karena perbedaan keyakinan. Tindakan-tindakan kekerasan bertentangan dengan UUD 1945 dan Pancasila. Setiap orang berhak untuk hidup di Negara Kesatuan Republik Indonesia (NKRI). Ketiga, para imam, ulama, dan tokoh-tokoh agama bisa menjadi penengah dalam konflik agama dan tindakan-tindakan kekerasan dengan melakukan dialog atau jalan damai sembari merujuk pada tradisi Islam. Tulisan ini diharapkan bisa diteliti dan dieksplorasikan lebih komprehensif di masa mendatang agar keharmonisan kehidupan beragama di Indonesia akan lebih baik.

Kata Kunci : Hubungan antaragama, kelompok-kelompok minoritas, tradisi Islam, dialog

\section{A. Introduction}

Religious tolerance and harmony in Indonesia are still considered better than other counties even though there are six officially religions (Islam, Protestantism, Catholicism, Hinduism, Buddhism, and Confucianism). In spite of happening intolerance cases, it was only isolated, casuistic, and can not reflect the condition of Indonesia as whole. ${ }^{1}$ Every religion has equal status. It shows that Indonesia has tradition of religious pluralism, enshrined in the state ideology of Pancasila. ${ }^{2}$ Besides that, founding President Sukarno has formulated that despite being different people, they all shared a "unity of historical experience" and are members of "one group, one nation". 3 The Indonesian stability is the fruit of the tolerant spirit and peaceful co-existence among all layers of the Indonesian population, ${ }^{4}$ the safest country in the world, ${ }^{5}$ and all religions stress on teachings of peace and serenity. ${ }^{6}$

Nevertheless, over the past two decades a combination of discriminatory laws and growing intolerance has resulted in harassment, intimidation

\footnotetext{
${ }^{1}$ Indonesia: Religious harmony remains strong in Indonesia, Asia News Monitor, Bangkok, 28 March 2018.

${ }^{2}$ Charles Maung Bo and Alissa Wahid, "Rejecting Religious Intolerance in Southeast Asia; Four Steps to Preserving the Diversity that Distinguishes This Region", Wall Street Journal (Online), New York, 27 September 2016.

${ }^{3}$ Raymond Lim, Indonesia: Ties That Bind in the Face of Sectarian Strife: Indonesia Faces the Challenge of Political Islam That Threatens to Rent Its Long-Cherished Unity in Diversity, The Straits Times, Singapore, 30 May 2017.

${ }^{4}$ This statement is said by King Salman bin Abdulaziz al-Saud when visiting Indonesia on 1-9 March 2017. Indonesia: King Salman Lauds Indonesia's Religious Harmony, Asia News Monitor, Bangkok, 7 March 2017.

5It is said by Yusnar Yusuf, The Chairman of the IndonsianUlema Council (MUI) in 2015. See Indonesia: Certain parties opposed to religious harmony in Indonesia - MUI, Asia News Monitor, Bangkok, 9 October 2015.

${ }^{6}$ Vice President Jusuf Kalla stressed that religion is not a source of conflict and violence but, in some occasions, is used by a handful of people to justify conflict and violence. Kalla addressed this remarks during the speech of his award of Honorary Doctor in the field of Religious Sociology from Alauddin National Islamic University in Makassar, South Sulawesi on January 25, 2018. See Indonesia: Religion Not A Source of Conflict, Violence - Kalla, Asia News Monitor, Bangkok, 29 January 2018.
} 
and violence against religious minorities. Setara Institute, an Indonesian NonGovernmental Organization (NGO), documented 201 violations of religious freedom targeting religious minorities in Indonesia in 2017 and 208 in 2016. Those violations - committed variously by government officials, police and militant Islamist groups - included 'intimidation, discrimination, assault, hate speech, bans on worship and sealing houses of worship'. Setara attributed these numbers to 'the strengthening and spread of intolerant organizations as well as weak governmental agencies and policies'?

The reality of interreligious relationship in Indonesia generally run well. Some various religious adherents respect each other, but so far a few groups - not to say militant Islam or fundamental-textual-legal Muslim - view outside of their groups as deviant sector "kafir". What's wrong with Indonesian Islam? This article aims to describe what is the meaning of interreligious relationship, how is the portrait of interreligious relationship in Indonesia, and how to foster tolerance and defend minority groups in the context of Indonesian Islam? This article is analyzed by using "the theory of interreligious relationship perspective".

\section{B. The Meaning of Interreligious Relationship}

The term 'interreligious' is defined differently, depending on what definition of 'religion' is implied. Mark C. Taylor's recent definition of religion serves this basic purpose: Religion is an emergent, complex, adaptive network of symbols, myths, and rituals that, on the one hand, figure schemata of feeling, thinking, and acting in ways that lend life meaning and purpose and, on the other, disrupt, dislocate, and disfigure every stabilizing structure. ${ }^{8}$ By deduction, 'religious' is whatever relates to religion as defined above. As for 'interreligious', can be defined as signifying the links and interactions between human beings, their thoughts and feelings, as well as their physical and immaterial constructions, when they pertain to two or more religions. ${ }^{9}$ When these interactions pertain to the diversity of perspectives within what might be called 'one religion', the term can be called 'intra-religious'. ${ }^{10}$ Interreligious relationship needs understanding from every believer when interacting. Thus, different thought and feelings from each believer can be united through dialogue.

In the context of the recent history of interreligious dialogue, it is important to explain interreligious relationship into a narrow and a broader definition. First, in a narrow definition of interreligious dialogue could be: human communication between religious leaders (often excluding or greatly reducing the participation of lay people and particularly of women) for the primary purpose of clarifying theological/philosophical similarities and differences. In many cases,

\footnotetext{
${ }^{7}$ Indonesia: Why Indonesia's Christian Diaspora Fears Going Home, Asia News Monitor, Bangkok, 6 March 2018.

${ }^{8}$ M. C. Taylor, After God (Chicago: The University of Chicago Press, 2007), 12; Ina Merdjanova and Patrice Brodeur, Religion as a Conversation Starter Interreligious Dialogue for Peacebuilding in the Balkans (London and New York: Continuum, 2009), 21.

${ }^{9}$ Merdjanova and Brodeu, Religion as a Conversation Starter, 21-22.

${ }^{10}$ Merdjanova and Brodeu, Religion as a Conversation Starter, 22.
} 
these encounters have led to the writing of various kinds of declarations and public statements, with specific but often limited impact. Second, a broader definition of interreligious dialogue could be: all forms of human communication both through speech and shared activities that help mutual understanding and cooperation between different people who self-identify religiously. ${ }^{11}$ The first interreligious relationship is more popular, namely interreligious dialogues done among religious leaders. But, the second interreligious relationship needs cooperative and mutual assistance in order conflict or violence caused by different belief, culture, tribe, and religion can be handled.

The definition of interreligious dialogue is also important to be explained. Leonard Swidler (1983) in his book "Dialogue Decalogue: Ground Rules for Interreligious, Interideological Dialogue"12 defines interreligious dialogue as follows: 1. Dialogue to learn, to change, and to grow, and act accordingly; 2 . Dialogue to share and receive from others; 3. Dialogue with honesty and sincerity; 4. Dialogue comparing ideals with ideals, and practice with practice; 5 . Dialogue to define yourself and to learn the self-definition of others; 6. Dialogue with no hardand-fast assumptions about someone else's beliefs; 7. Dialogue to share with equals; 8. Dialogue in trust; 9. Dialogue with willingness to look at your beliefs and traditions critically; and 10. Dialogue seeking to understand the other person's beliefs fromwithin.

The above interreligious dialogues strongly support elements to overcome conflict and violence in the name of religion. Interfaith peace-makers are often featured as figures trying to resolve conflicts in the name of religion. But, there is no empirical or social scientific evidence to demonstrate that religion is no more or no less a source of violence than the law, or cultural narratives, or stories. There is nothing inherent in religion and religious belief that fates religion toward violence or peace. Religion is equally capable of serving as an underlying ideology for violent extremists, as well as a source of inspiration for those whom Scott Appleby has called militants for peace. ${ }^{13}$ Peace must be understood and implemented by every believer. Hans Küng said "No peace among nations without peace among the religions. No peace among the religions without dialogue between the religions. No dialogue between the religions without investigation of the foundation of the religions." 14 The Indian bishops added: "In a country and a continent of many living religions, to be religious itself means to be interreligious -

\footnotetext{
${ }^{11}$ Merdjanova and Brodeu, Religion as a Conversation Starter, 3.

${ }^{12}$ Leonard Swidler, Dialogue for Interreligious Understanding Strategies for the Transformation of Culture-Shaping Institutions (New York: Palgrave Macmillan, 2014), 47-51; Merdjanova and Brodeu, Religion as a Conversation Starter, 15.

${ }^{13}$ R.S. Appleby, The Ambivalence of the Sacred: Religion, Violence, and Reconciliation (Rowman \& Littlefield Publishers, Lanham, 2000).

${ }^{14}$ Hans Küng, Global Responsibility: In Search of a New World Ethic, trans. John Bowden (Crossroad, New York, 1991), xv; Peter C. Phan, "Peacekeeping, Peacemaking, Peacebuilding: An Interreligious Spirituality for Just Peace", in Violence, Religion, Peacemaking, Douglas IrvinErickson and Peter C. Phan, eds. (New York: Palgrave Macmillan, 2016), 22.
} 
that is, to live amicably in dialogue. ${ }^{15}$ Indeed, many are responding to current conflict by demonstrating respect and by developing more peaceful relationships. Interreligious conflicts must be overcome unless, according to Charles Kimball, more wars have been waged, more people killed, and these days more evil perpetrated in the name of religion than by any other institutional force in human history. ${ }^{16}$

In contemporary era, interreligious relations are as much a matter of good diplomacy as they are of proper theology. Diplomacy involves establishing formal or semiformal relations, which have representative and symbolic value. ${ }^{17}$ The modern practice of interreligious dialogue is also one way of responding to the increasing religious diversity in the world with the intention of contributing to more social harmony. The value of interreligious dialogue has been widely acknowledged, particularly with regard to its potential for prevention, mediation and resolution of conflicts, and to fostering a better understanding between individuals within a society.

At the heart of interreligious theological responsibility is the recognition that God alone counts and that we must look for God and His reality in the encounter with others. The difficulties in approaching religion from various problems are involving in God law where every religion has different procedure and regulations. As it has been known that God law teaches human being to behave 'just', so interreligious solidarity must implement 'justice'.

\section{The Portrait of Interreligious Relationship in Indonesia}

Indonesia is a country that can be an example of peaceful Islamic practices, democracy, modernity, and interreligious tolerance. ${ }^{18}$ Indonesian Islam strongly supports interreligious relationship and at the same time maintains democracy. ${ }^{19}$ Even, when there was questioning "Does democracy in Indonesia undergo transition after Arab spring?" ${ }^{20}$ in fact it was not proven. Thomas Peinsky

${ }^{15}$ Edmund Kee-Fook Chia, "Response of the Asian Church to Nostra Aetat", in Interfaith Dialogue: Global Perspectives, Edmund Kee-Fook Chia, ed. (New York: Palgrave Macmillan, 2016), 53.

${ }^{16}$ Charles Kimball, When Religion Becomes Evil (Canada: HarperCollins, 2002), 1.

${ }^{17}$ Alon Goshen-Gottstein, Same God, Other God Judaism, Hinduism, and the Problem of Idolatry (London: Palgrave Macmillan, 2016), 197.

${ }^{18}$ This statement was delivered by Bill Clinton (The former of The President of The United States of America) when visiting Indonesia in 2009. Clinton said "If you want to know whether Islam, democracy, modernity, and woman rights can live together, go to Indonesia, please". James B. Hoesterey, "Is Indonesia a Model for the Arab Spring? Islam, Democracy, and Diplomacy", Review of Middle East Studies, Vol. 47, No. 1 (Summer 2013): 56-62.

${ }^{19}$ Fred R. von der Mehden, Islam in Indonesia in the Twenty-First Century, in Asian Islam in the 21st Century, John L. Esposito John, O. Voll, and Osman Bakar (Oxford and New York: Oxford University Press, 2008), 19.

${ }^{20}$ Arab Spring (al-Tsauraat al-'Arabiyyah: The rise of the Arab World) is a massive protest or demand by intellectuals, liberal figures, public figures, and opposition groups to criticize the Arab regime, which starts from 17 December 2010 to mid 2012. The Arab Spring starts from Tunisia and continues to Egypt, Libya, Yemen, Bahrain, Syria, Jordan, Algeria, Morocco, Iraq and Oman. Algeria, Kuwait, Lebanon, Mauritania, Saudi Arabia, and South Sudan. The triggers are price 
explained that there was no Arab Spring model in Indonesia. ${ }^{21}$ Thomas Carothers assured the world that Indonesia could still be an example of a successful democracy $^{22}$ and unaffected Arab Spring. Both Carothers and Pepinsky explain that Indonesia is different from the Arab World, even the middle eastern people can learn democracy and maintain harmony among religious communities in Indonesia. ${ }^{23}$ Indonesian Islam, as Barack Obama and Hillary Clinton said when visiting Indonesia a few years ago, is a "tolerant Islam", which is expected to be an example of Muslim-style democracy.

Nevertheless, Human Rights Watch wrote, in the New York Times (May 21, 2012) entitled "No Model for Muslim Democracy", that in Indonesia is still encountered violations of religious freedom and intolerant acts. ${ }^{24}$ Indonesia still finds radical elements and acts of terror. ${ }^{25}$ Martin van Bruinessen and Kikue Hamayotsu say that there are still anti-liberal groups, radical movements, and conservatives despite the democratic consolidation in Indonesia. Bruinessen and

increases, unemployment, corruption, political stagnation, human rights violations, inflation, sectarianism, and undemocratic government attitudes. The objectives of this protest are democratic, fair, just and clean elections, economic freedom, human rights, occupation, regime change, and Islamism. See, Irawan, Diskursus Pluralisme Agama dan Relevansinya dalam Konteks Kehidupan Beragama di Indonesia (Ciputat, Tangerang Selatan: Onglam Books, 2017), 332.

${ }^{21}$ Thomas Pepinsky, “There Is No Indonesia Model for the Arab Spring”, Foreign Policy. com/articles/2013/02/27/there_is_no_indonesia_model_for_the_arab_spring. Accessed on 17 May 2016.

${ }^{22}$ Thomas Carothers, "Egypt and Indonesia," New Republic, February 2, 2011. www.newrepublic.com/article/world/82650/egypt-and-indonesia. Accessed on 17 May 2018.

${ }^{23}$ GioraEliraz, "http://www.mei.edu/content/map/reflections-post-arab-spring-landscapesailing-thoughts-indonesia." Middle East Institute, October 20, 2014. www.mei.edu/content/map/ref lections-post-arab-spring-landscape-sailing-thoughts-indonesia.Accessed on 17 May 2018.

${ }^{24}$ Andreas Harsono, "No Model for Muslim Democracy", New York Times, 21 May 2012.

${ }^{25}$ Mehden, "Islam in Indonesia in the Twenty-First Century", 17.Since the beginning of May 2018, at least 49 Indonesians - 12 civilians, seven police officers and 30 terrorists — have died in back-to-back attacks by ISIS supporters or government antiterrorism operations. Sidney Jones, How ISIS Has Changed Terrorism in Indonesia, The New York Times, International Edition, New York, 23 May 2018. On 13 May 2018, three churches in Surabaya were targeted by suicide bombings, believed to have been carried out by a family linked to the local cell of the ISIS - inspired Jamaah Ansharut Daulah (JAD) radical group. In this incident, the family of six - including girls aged nine and 12 - had apparently returned from Syria recently. In the Sunday attacks, the father used a car with explosives, the sons drove motorbikes with explosives while the mother and two daughters detonated a bomb at three separate churches. At least 13 people were killed. See Indonesia Social Media Slams Use of Children in Church Bombings, BBC Monitoring Asia Pacific, London, 14 May 2018. A riot broke out among prisoners at the Mako Brimob detention centre in Kelapa Dua, Depok, West Java, on Tuesday night (8/5/2018) until Wednesday (9/5/2018) at dawn. The incident left five policemen and one inmate dead. Indonesia: Indonesia will not flinch in war against terrorism - Jokowi, Asia News Monitor, Bangkok, 14 May 2018.In Riau, one policeman was killed and 4 militants were shot dead in an attack on a police headquarters in Riau province of Indonesia (on Wednesday, May 16, 2018). The attack comes days after a series of terrorist strikes in the country, including suicide bombings in three churches on Sunday in Surabaya city, the provincial capital of East Java and a suicide bombing at the police headquarters in the city, which left at least 25 people dead and dozens of others injured. See Deadly Terrorist Attack on Indonesia Police Headquarters, Iran Daily; Tehran, 16 May 2018. 
Hamayotsu's opinion is contrary to what Rober W. Hefner said that the Indonesian Islamic tradition as "civil Islam". 26

How is the portrait of interreligious relationship in Indonesia? Interreligious relationship in this country is still running unwell. According to Alexander De Juan, Jan H. Pierskalla, and Johannes Vüllers'research, there are more than 60,000 villages in Indonesia in which local religious institutions probability do mass fighting and violence. Two prominent cases of interreligious violence in Indonesia (for example Maluku and Sulawesi) can't be solved because religious institutions fail to mediate (or even contribute to) communal violence. First, the peace impact of religious institutions possibly declines once a manifest interreligious conflict begins. Second, some of the main violent actors did not come from the local villages in Maluku and Sulawesi. Religious institutions are likely limited in their ability to substantively influence outsiders, who - similar to recent migrants - are not as heavily integrated into the local religious institutions and are therefore less likely to be affected by horizontal and vertical linkages. ${ }^{27}$

Many places in Indonesia have potential issues that may lead to interreligious conflicts such as between Muslims and Christians, or any incident too substantial to be considered as merely misunderstanding. The public may still easily recollect how conflicts could affect vast areas and prolong, causing serious damages in the past decades. ${ }^{28}$

Furthermore, there are three types of religious conflict in Indonesia, namely: conflict between adherents of different religions (interreligious), such as those between Muslims and Christians; conflict between adherents of a particular religion and a strand of the religion deemed deviant, such as those between Muslims and Ahmadiyah followers; conflict between adherents of a religion with different theological understanding, such as those between Sunni and Shia Muslims. $^{29}$ Take these examples: the 1995 case in East-Timor (before its independence from Indonesia), the 1997 case in Situbondo, the cases in Pontianak, Ambon, Poso in 2001, and the conflict between Madura and Dayak ethnic tribes in

\footnotetext{
${ }^{26}$ Rober W. Hefner, Civil Islam: Muslims and Democratization in Indonesia (Princeton and Oxford: Princeton University Press, 2000), 29.

${ }^{27}$ Alexander De Juan, et. al, "The Pacifying Effects of Local Religious Institutions: An Analysis of Communal Violence in Indonesia", Political Research Quarterly, Vol. 68(2) (2015): 211-224.

${ }^{28}$ Faisal Ismail, Pijar-pijar Islam PergumulanKulturdanStruktur, Cet. ke-1 (Yogyakarta: LembagaStudiFilsafat Islam, 2002), 222-223; AbuddinNata, et. al, Jewel From Heaven: Portrait of Religious Lives in Indonesia (Jakarta: Directorate of Public Diplomacy Directorate General of Information and Public Diplomacy The Ministry of Foreign Affairs Republic of Indonesia In cooperation with Research and Community Service Agency State Islamic University SyarifHidayatullah Jakarta, 2016), 2.

${ }^{29}$ AndikWahyunMuqoyyidin (2012), "Potret Konflik Bernuansa Agama di Indonesia (Signifikansi Model ResolusiBerbasisTeologiTransformatif)", Analisis, Vol. XII, No. 2, December. Retrieved from https:// www. academia. edu/4900906/, Potret Konflik Bernuansa Agama di Indonesia, Signifikansi, Model Resolusi Berbasis Teologi Transformatif. Accessed on May 17 2018; See also SyahrinHarahap, "The Image of Indonesia in the World: An Interreligious Perspective", The IUP Journal of International Relations, Vol. X, No. 2 (2016): 30-44.
} 
Sampit, Central Kalimantan in 2001. These cases are recorded in the national history, disturbing peace and tolerance among followers of religion. ${ }^{30}$

Additionally, the conflict of religious intolerance happened in Jayapura (the capital of Papua Province). A Christian group in Jayapura recently issued a stark 14-day ultimatum to municipal authorities: Dismantle the minaret of the city's Al-Aqsa mosque by the end of February 2018 or the group would take their own action. ${ }^{31}$ This case shows that majority religious group does not tolerate with minority religious group. Another conflict is the difference of doctrine between Sunnis and Shias. In 2012, an East Java branch of the National Ulama Council issued a fatwa against Shia Muslims, calling them deviants, and the same year, several Shia were driven out of their homes. There has been a trickle of anti-Shia violence since then, and in 2014, a National Anti-Shia Alliance of Indonesia was founded in Bandung, West Java. ${ }^{32}$

Some thinkers analyze that interreligious relationship gets more postSoeharto (former President of Indonesia, 12 Maret 1967 - 21 Mei 1998). Syahrin Harahap classifies the image of Indonesia into three categories. First, interreligious relationship is as more harmonious, open, and fair, due to implementation of legal reforms, such as the Law on House of Worship, in which non-Muslim houses of worship have increased by more than $300 \%$, and the fact that Susilo Bambang Yudhoyono and several regional governments have been given 'peace' awards by foreign institutions. Second, Indonesian society as secular, liberal and westernoriented, due to its religious openness which exceed other Muslim societies in Southeast Asia and the world. Third, Indonesia is the place where various religious tensions or conflicts occur between different religious communities, religious schools of thoughts, as well as the place for the existence of religious fanaticism, and the involvement of religious community members in terroristic acts. ${ }^{33}$ To enhance the positive image of Indonesia's interreligious relationship in the world,

\footnotetext{
${ }^{30} \mathrm{Nata}$, et. al, Jewel From Heaven, 2 .
}

${ }^{31}$ Indonesia: Religious Harmony Principle Backfires in Indonesia, Asia News Monitor, Bangkok, 25 April 2018. As quoted in this Asia News Monitor, The International Covenant on Civil and Political Rights, which Indonesia ratified in 2005, states that persons belonging to...minorities shall not be denied the right, in community with the other members of their group, to enjoy their own culture, to profess and practice their own religion. To respond this, President Joko Widodo should endorse religious freedom as a fundamental principle of his administration and ensure that government officials are not promoting abuses against religious minorities. The Jayapura case should be an opportunity to educate the Indonesian public that this majority-minorities regulation is nothing less than a legal tool to discriminate against religious minorities that erodes, rather than strengthens, Indonesia's pluralism.

${ }^{32}$ Iran/Indonesia: Iran-Funded Center a Lifeline for Jakarta's Marginalized Shia Minority, Asia News Monitor; Bangkok, 6 October 2017. In this Asia News Monitor is also explained that over 99 percent of Indonesian Muslims belong to the Sunni denomination, but that belies Shia cultural influence in the world's largest Muslim-majority country (Both Sunni and Shia are the two major Muslim denominations, which diverged early in Islamic history over a debate on the rightful successors to the prophet.). Shia Islam may have been the first strain to reach Indonesia, through Arab traders who reached Aceh around the 12th century, and Shia traditions like ancestor worship and feast days for saints are still observed in pockets across Indonesia, even by Sunnis.

${ }^{33}$ Harahap, "The Image of Indonesia in the World", 30-44. 
Harahap suggests that it is important to perform various actions, especially in the perspective of interreligious relationship, such as providing a more just service to the religious community through 'remoderation', informing the world of positive interfaith relations in Indonesia, and expanding the horizon communities and communities in Indonesia through the study of globalization.

What have been done by government and decision makers to handle the interreligious relationship conflict? The religious rights protection bill, which is expected to go before parliament by the end of 2017, enshrines both Indonesia's abusive blasphemy law and decrees which restrict religious minorities seeking to construct houses of worship. The draft law also imposes excessively narrow criteria for a religion to receive state recognition, and increases the powers of the discriminatory official Religious Harmony (Forum Kerukunan Umat Beragama or FKUB). ${ }^{34}$ The Indonesian government apparatus and religious leaders should always remind people about the joy of peace, brotherhood, harmony, and unity. ${ }^{35}$ Besides that, both the government apparatus and religious leaders should not only work together to foster Indonesia as solid, tolerant, and mutual understanding nation, but also keep in a synergy to maintain the education quality and Indonesian people attitude.

\section{Fostering Tolerance and Defending Minority Groups in the Context of Indonesian Islam}

Each religion has its own characteristics and fosters a strong horizontal networks. ${ }^{36}$ In many cases, religion that a person believes is not a choice from birth, so it is only natural that his presence in the world tends to constitute a heterogeneous society. ${ }^{37}$ Moreover, religious ceremonies and prayer involve the repeated interaction of individuals from various socio cultural backgrounds. Finally, religion engenders norms that foster interreligious cooperation among such different group.

The challenge for Indonesian society and government is to avoid its negative impacts and to optimize its positive sides, such as fostering tolerance and democratic values. ${ }^{38}$ How to foster tolerance in Indonesia in which there are various religion? As it has been explained before, Setara Institute wrote 201 July 2017

${ }^{34}$ Indonesia: 'Religious Rights' Bill Would Harm Minorities, Asia News MonitorBangkok, 24

${ }^{35}$ The statement was made by President Joko "Jokowi" Widodo in a remarks during Religious Leaders Conference for National Harmony on Saturday (February 10, 2018), at the Bogor Presidential Palace, West Java.

${ }^{36}$ Paula M. Pickering, "Generating Social Capital for Bridging Ethnic Divisions in the Balkans: Case Studies of Two Bosniak Cities",Ethnic and Racial Studies, 29, 1 (2006): 79-103.

${ }^{37}$ Nancy T. Ammerman, "Religious Identities and Religious Institutions" in Handbook of the Sociology of Religion, edited by Michele Dillon (Cambridge: Cambridge University Press, 2003), 207-224

${ }^{38}$ ArisAnanta, "Commentary Demand for Democracy in Indonesia: A Demographic Perspective”, Asian Population Studies, Vol. 2, No. 1 (March 2006): 1-2. 
violations of religious freedom targeting religious minorities in Indonesia (2017) and 208 (2016). Violence and intolerance actions had not happened if religious leaders and imams would have supported every believer to be tolerant people.

Abdullah Saeed suggests that the most effective means of developing a culture of religious tolerance and respect in a multi-religious, but predominantly Muslim society, is by reforming the education of its leaders - the imams and religious guides of the community. The imams are graduates of traditional Islamic educational institutions. They are the public face of Islam; the community relies on them for its understanding of what is or is not acceptable in religion. Their close relationships with their communities mean that they not only lead worship and teach, but are also often involved in community development. Their religious training forms their view of the religious 'other' as friend or foe, trustworthy or otherwise, and ultimately, contributes significantly towards shaping the outlook of the community in relation to other faiths. ${ }^{39}$ This statement is relevant to Leonard Swidler's theory that imams and religious leaders have to perform dialogue to seek to understand the other person's beliefs or doctrine. Imams and religious leaders in Indonesia can position themselves as problem solver in conflict situation or violence acts in the name of religion.

Saeed emphasized that education is a solution of conflict and interreligious violence. The education of imams and religious leaders provides positive view, bias, prejudice and religious beliefs. Imams and religious leaders can guide believers in tolerating, accepting, and rejecting differences. Although historical, socio-political, and economic factors play an important role in the formation of such attitudes towards 'the other', in a largely religious society, is often a religious factor which is seen to guide believers in tolerating, accepting, or rejecting differences. This educational factor also drives the reformist period of modern Islam, such as Ahmad Khan, Muhammad Abduh, Muhammad Iqbal, Hassan alBanna, Ismail Faruqi and Abu al-AlaMawdudi, to establish an educational institution.

Education learnt from Islamic tradition has good epistemology for future Islam. Seyyed Hossein Nasr has stated that "the future of the world in the next few years and decades will depend obviously on how various world views and civilizations will be able to live together" ${ }^{40}$ One of the important strategies to be able to "live together" is "a hermeneutic of tolerance" that encourages mutual respect, goodwill, and proactive engagement across and within cultures and religious traditions.

${ }^{39}$ Abdullah Saeed, "Towards Religious Tolerance through Reform in Islamic Education: The Case of The State Institute of Islamic Studies of Indonesia", Indonesia and the Malay World, Vol. 27, No. 79 (1999): 177-191.

${ }^{40}$ Seyyed Hossein Nasr, "Metaphysical Roots of Tolerance and Intolerance: An Islamic Interpretation," in Philosophy, Religion, and the Question of Intolerance, Mehdi Amin Razavi and David Ambuel, eds. (Albany, NY: State University of New York, 1997), 55; Aaron Tyler, "Tolerance as a Source of Peace: Gülen and the Islamic Conceptualization of Tolerance", Islam in the Age of Global Challenges - Conference Proceedings, 2008, 730. 
Furthermore, to occur tolerance, group members should judge intergroup differences as normative and valuable, thereby fostering their appreciation and acceptance of out-group. But, this positive evaluation toward intergroup differences requires one condition: a super-ordinate category that transcends and includes both in-group and out-group. On this subject, tolerance is defined as the representation of a super-ordinate category in such an inclusive way in order to include out-groups and recognize their positive and normative existence. On the contrary, intolerance evolves from the claim that the in-group is the most prototypical or representative of a super-ordinate category, which in turn becomes an exclusive criterion to evaluate out-group. ${ }^{41}$

The intolerance interreligious relationship in Indonesia also happen recently. The terrorist attacks happened: 1 . On Tuesday night (May 8, 2018) until Wednesday (May 9, 2018) at dawn in Kelapa Dua, Depok, West Java happened a riot 2. On May 13, 2018 (three churches were bombed in Surabaya and killed the family of six - including girls aged nine and 12) 3. On May 14, 2018 (police headquarters in Surabaya was bombed) 4. On May 16, 2018 (In Riau, one policeman was killed and 4 militants were shot dead in an attack on a police headquarters in Riau province of Indonesia). Certainly, these cases must be handled by hard approach and soft approach. Hard approach means that terrorism can be tackled by Indonesian soldiers, Indonesian policemen, and all elements of society. Whereas soft approach can be coped with by religious leaders or religious figures by teaching, preaching, and doing dialogue with terrorist followers in order they can be open-minded about Islam, especially the meaning of jihad. Islam must be understood as "peace religion" (rahmatan li al- 'alamin). This dialogue model is relevant to Hans Küng's opinion that every believer must make nation become peaceful, and different opinion of religious view must be disscussed together by investigating the foundation of the religions.

The greatest lesson of today's generation can impart to succeeding generations is "how to forgive" wrong doing in a spirit of tolerance and reconciliation. ${ }^{42}$ From Gülen's Muslim perspective, interreligious reconciliation requires forgiveness - through truth-telling and repentance - to be extended to all those who express repentance for the violence or persecution they perpetrated. Such forgiveness can only be expressed through a spirit of tolerance, whereby the transgressions of others are not forgotten, but overlooked or pardoned for higher purposes of God and community. The "greatest exemplars of humanity" are those who have demonstrated "the greatest forgiveness and the most impeccable tolerance". ${ }^{43}$

${ }^{41}$ A. Mashuri, et. al, "Examining Predictors of Tolerance and Helping for Islamic Religious Minorities in Indonesia”, International Journal of Research Studies in Psychology, Volume 3 Number 2 (April 2014): 15-28.

${ }^{42}$ M. F. Gülen, The Necessity of Interfaith Dialogue: A Muslim Perspective (Somerset: Light, 2004), 21-22.Tyler, "Tolerance as a Source of Peace", 749.

${ }^{43}$ M. F. Gülen, Toward a Global Civilization of Love \& Tolerance (New Jersey, Light, 2006), 29; Tyler, "Tolerance as a Source of Peace", 749. 
The greatest forgiveness and the most impeccable tolerance for Indonesian people are relevant to Indonesian national motto Bhinneka Tunggal Ika (Unity in Diversity), which constitutes an ideological legitimacy for the Indonesian people to express and maintain their diverse ethnicities, cultures, and religions, has recently received incisive criticism. The core issue of this criticism is revolving around the Islamist militant groups' brutal attacks on members of religious minority groups and their houses of worship. ${ }^{44}$

Beside Bhinneka Tunggal Ika, Pancasila - as stated by Abdurrahman Wahid or Gus Dur - is the guarantee of freedom of religion not only to embrace religion but also the role of religious "ethics of society" in public space, ${ }^{45}$ democracy principle and human rights. ${ }^{46}$ Nurcholish Madjid or Cak Nur also explains that Pancasila is defined as a 'kalimahsawa' (Commond Word) - or or a meeting point of pluralism $-{ }^{47}$ for Indonesia, past, present, and future.

Islam, as majority in Indonesia, must be understood by its adherents as "silmi" religion (peace religion) which respects other Muslim or other beliefs. Gus Dur called it with the term Islamku, Islam Kita, Islam Anda(My Islam, Our Islam, Your Islam). According to Gus Dur, everyone should not impose belief on others (My Islam). Because in religious tradition or rituals that live in the society are beliefs and differences believed by certain people which have to be respected (Your Islam). Although everyone has different beliefs, every Muslim must create peace (al-silmi) and the common interest of Muslims (Our Islam). ${ }^{48}$ Islam should be apprehended inclusively, democratically, and pluralistically. ${ }^{49}$ Therefore, in Azyumardi Azra's opinion, Indonesian Islam is not as rigid as Middle East Islam. Indonesian Islam is "Islam with a smiling face", namely Islam which in many ways fits perfectly with modernity, democracy, and plurality. ${ }^{50}$ Every Indonesian society gets the same rights as a citizen. In The 1945 Constitution is mentioned that everyone is protected their human rights, which cover the protection of the law, the treatment of justice, the provision of basic necessities, the enhancement of intelligence, the giving of freedom of expression and association, and the freedom

\footnotetext{
${ }^{44}$ Mashuri, et. al, "Examining Predictors of Tolerance and Helping for Islamic Religious Minorities in Indonesia", 15-28.

${ }^{45}$ Abdurrahman Wahid, PrismaPemikiran Gus Dur (Yogyakarta: LKiS, 2000), 213-214.

${ }^{46}$ Lihat Douglas E. Ramage, Politics in Indonesia: Democracy, Islam and the Ideology of Tolerance (London: Routledge, 1995), 45-74; Mujiburrahman, Feeling Threatened: Muslim-Christian Relations in Indonesia's New Order (Leiden: Amsterdam University Press, 2006), 152.

${ }^{47}$ Cak Nur refers to Qs. Ali Imran (3): 64, Say, "O People of the Scripture, come to a word that is equitable between us and you - that we will not worship except Allah and not associate anything with Him and not take one another as lords instead of Allah." But if they turn away, then say, "Bear witness that we are Muslims [submitting to Him]."

${ }^{48}$ Abdurrahman Wahid, Islamku Islam Anda Islam Kita: Agama Masyarakat Negara Demokrasi, Cet. ke-1 (Jakarta: The Wahid Institute, 2006).

${ }^{49}$ John L. Esposito and John O.Voll, Makers of Contemporary Islam (NewYork: Oxford University Press, 2001), 206.

${ }^{\mathbf{5 0}}$ Azyumardi Azra, Indonesia, Islam, and Democracy: Dynamics in a Global Context (Jakarta: Solstice, 2006), 124.
} 
of belief and faith. ${ }^{51}$ The fulfillment of these basic rights can contribute greatly in maintaining the integrity of the Unitary State of the Republic of Indonesia (NKRI).

\section{E. Conclusion}

This study potentially contributes some significance in the sense that it is the first to research the phenomenon of religious life between Islamic minority groups and the Islamic majority responses in Indonesia. This study is qualitative approach by using interreligious relationship theory.

This study can be concluded that: The first, Indonesia has various religions (Islam, Protestantism, Catholicism, Hinduism, Buddhism, and Confucianism), so it is possible to happen conflict and intolerance. To avoid this, every must return to what Sukarno or our founding father had formulated that despite being different people, we are one nation with the motto Bhinneka Tunggal Ika (Unity in Diversity). The second, Islamic minority groups or minority religious adherents are not allowed to be oppressed by any other groups because of different belief. The violent acts are contrary to the 1945 Constitution and Pancasila. Everyone has right to live in the Unitary State of the Republic of Indonesia (NKRI). The third, imams, ulamas, and religious leaders can function to be deterrent in religion conflict and violent acts by doing dialogue or win-win solution while referring to Islamic traditions.

\section{References}

Ammerman, Nancy T. "Religious Identities and Religious Institutions" in Handbook of the Sociology of Religion, edited by Michele Dillon. Cambridge: Cambridge University Press, 2003.

Ananta, Aris. "Commentary Demand for Democracy in Indonesia: A Demographic Perspective". Asian Population Studies, Vol. 2, No. 1 (March 2006): 1-2.

Appleby, R.S. The Ambivalence of the Sacred: Religion, Violence, and Reconciliation. Rowman \& Littlefield Publishers, Lanham, 2000.

Aziz, Ahmad Amir. Neo-Modernisme Islam di Indonesia:

GagasanSentralNurcholishMadjiddan Abdurrahman Wahid. Jakarta: PT. RenekaCipta, 1999.

Azra, Azyumardi. Indonesia, Islam, and Democracy: Dynamics in a Global Context. Jakarta: Solstice, 2006.

Bo, Charles Maung and Wahid, Alissa. "Rejecting Religious Intolerance in Southeast Asia; Four Steps to Preserving the Diversity that Distinguishes This Region”. Wall Street Journal (Online), New York, 27 September 2016.

Carothers, Thomas. "Egypt and Indonesia," New Republic, February 2, 2011. www.newrepublic.com/article/world/82650/egypt-and-indonesia. Accessed on 17 May 2018.

${ }^{51}$ Ahmad Amir Aziz, Neo-Modernisme Islam di Indonesia: Gagasan Sentral Nurcholish Madjid dan Abdurrahman Wahid (Jakarta: PT. RenekaCipta, 1999), 33. 
Chia, Edmund Kee-Fook. "Response of the Asian Church to Nostra Aetat", in Interfaith Dialogue: Global Perspectives, Edmund Kee-Fook Chia, ed. New York: Palgrave Macmillan, 2016.

Deadly Terrorist Attack on Indonesia Police Headquarters.Iran Daily; Tehran, 16 May 2018.

Eliraz, Giora. "http://www.mei.edu/content/map/reflections-post-arab-springlandscape-sailing-thoughts-indonesia." Middle East Institute, October 20, 2014. www.mei.edu/content/map/ref lections-post-arab-spring-landscapesailing-thoughts-indonesia. Accessed on 17 May 2018.

Esposito, John L. and Voll, John O. Makers of Contemporary Islam.NewYork: Oxford University Press, 2001.

Goshen-Gottstein, Alon. Same God, Other God Judaism, Hinduism, and the Problem of Idolatry. London:Palgrave Macmillan, 2016.

Gülen, M. F. The Necessity of Interfaith Dialogue: A Muslim Perspective. Somerset: Light, 2004.

Toward a Global Civilization of Love \& Tolerance. New Jersey, Light, 2006.

Harsono, Andreas. "No Model for Muslim Democracy". New York Times, 21 May 2012.

Hefner, Rober W. Civil Islam: Muslims and Democratization in Indonesia.

Princeton and Oxford: Princeton University Press, 2000.

Hoesterey, James B. "Is Indonesia a Model for the Arab Spring? Islam,

Democracy, and Diplomacy". Review of Middle East Studies, Vol. 47, No. 1 (Summer 2013): 56-62.

Indonesia Social Media Slams Use of Children in Church Bombings. $B B C$ Monitoring Asia Pacific, London, 14 May 2018.

Indonesia: 'Religious Rights' Bill Would Harm Minorities. Asia News MonitorBangkok, 24 July 2017.

Indonesia: Certain parties opposed to religious harmony in Indonesia - MUI. Asia News Monitor, Bangkok, 9 October 2015.

Indonesia: Indonesia will not flinch in war against terrorism - Jokowi. Asia News Monitor, Bangkok, 14 May 2018.

Indonesia: King Salman Lauds Indonesia's Religious Harmony. Asia News Monitor, Bangkok, 7 March 2017.

Indonesia: Religion Not A Source of Conflict, Violence - Kalla. Asia News Monitor, Bangkok, 29 January 2018.

Indonesia: Religious Harmony Principle Backfires in Indonesia. Asia News Monitor, Bangkok, 25 April 2018.

Indonesia: Religious harmony remains strong in Indonesia. Asia News Monitor, Bangkok, 28 March 2018.

Indonesia: Why Indonesia's Christian Diaspora Fears Going Home. Asia News Monitor, Bangkok, 6 March 2018.

Iran/Indonesia: Iran-Funded Center a Lifeline for Jakarta's Marginalized Shia Minority. Asia News Monitor. Bangkok, 6 October 2017. 
Irawan, Diskursus Pluralisme Agama dan Relevansinya dalam Konteks Kehidupan Beragama di Indonesia. Ciputat, Tangsel: Onglam Books, 2017.

Ismail, Faisal. Pijar-pijar Islam Pergumulan Kulturdan Struktur, Cet. ke-1. Yogyakarta: Lembaga Studi Filsafat Islam, 2002.

Jones, Sidney. How ISIS Has Changed Terrorism in Indonesia. The New York Times, International Edition, New York, 23 May 2018.

Juan, Alexander De, et. al, "The Pacifying Effects of Local Religious Institutions: An Analysis of Communal Violence in Indonesia", Political Research Quarterly, Vol. 68(2) (2015): 211-224.

Kimball, Charles. When Religion Becomes Evil.Canada: HarperCollins, 2002.

Küng, Hans. Global Responsibility: In Search of a New World Ethic, trans. John Bowden. Crossroad, New York, 1991.

Lim, Raymond. Indonesia: Ties That Bind in the Face of Sectarian Strife: Indonesia Faces the Challenge of Political Islam That Threatens to Rent Its Long-Cherished Unity in Diversity, The Straits Times, Singapore, 30 May 2017.

Mashuri, A., et. al, "Examining Predictors of Tolerance and Helping for Islamic Religious Minorities in Indonesia". International Journal of Research Studies in Psychology, Volume 3 Number 2 (April 2014): 15-28.

Merdjanova, Ina and Brodeur, Patrice.Religion as a Conversation Starter Interreligious Dialogue for Peacebuilding in the Balkans. London and New York: Continuum, 2009.

Mujiburrahman.Feeling Threatened: Muslim-Christian Relations in Indonesia's New Order. Leiden: Amsterdam University Press, 2006.

Muqoyyidin, AndikWahyun (2012), "Potret Konflik Bernuansa Agama di Indonesia (Signifikansi Model Resolusi Berbasis Teologi Transformatif)", Analisis, Vol. XII, No. 2, December. Retrieved from https:// www. academia. edu/4900906/, Potret Konflik Bernuansa Agama di Indonesia, Signifikansi, Model Resolusi Berbasis Teologi Transformatif. Accessed on May 172018.

Harahap, Syahrin. "The Image of Indonesia in the World: An Interreligious Perspective". The IUP Journal of International Relations, Vol. X, No. 2 (2016): 30-44.

Nasr, SeyyedHossein. "Metaphysical Roots of Tolerance and Intolerance: An Islamic Interpretation," in Philosophy, Religion, and the Question of Intolerance, Mehdi Amin Razavi and David Ambuel, eds. Albany, NY: State University of New York, 1997.

Nata, Abuddin, et. al, Jewel From Heaven: Portrait of Religious Lives in Indonesia. Jakarta: Directorate of Public Diplomacy Directorate General of Information and Public Diplomacy The Ministry of Foreign Affairs Republic of Indonesia In cooperation with Research and Community Service Agency State Islamic University Syarif Hidayatullah Jakarta, 2016.

Pepinsky, Thomas. "There Is No Indonesia Model for the Arab Spring", Foreign Policy. com/articles/2013/02/27/there_is_no_indonesia_model_for_the_ arab_spring. Accessed on 17 May 2016. 
Phan, Peter C. "Peacekeeping, Peacemaking, Peacebuilding: An Interreligious Spirituality for Just Peace", in Violence, Religion, Peacemaking, Douglas Irvin-Erickson and Peter C. Phan, eds. New York: Palgrave Macmillan, 2016. Pickering, Paula M. "Generating Social Capital for Bridging Ethnic Divisions in the Balkans: Case Studies of Two Bosniak Cities". Ethnic and Racial Studies, 29, 1 (2006): 79-103.

Ramage, Douglas E. Politics in Indonesia: Democracy, Islam and the Ideology of Tolerance. London: Routledge, 1995.

Saeed, Abdullah. "Towards Religious Tolerance through Reform in Islamic

Education: The Case of The State Institute of Islamic Studies of Indonesia".

Indonesia and the Malay World, Vol. 27, No. 79 (1999): 177-191.

Swidler, Leonard. Dialogue for Interreligious Understanding Strategies for the

Transformation of Culture-Shaping Institutions. New York: Palgrave Macmillan, 2014.

Taylor, M. C. After God. Chicago: The University of Chicago Press, 2007.

Tyler, Aaron. "Tolerance as a Source of Peace: Gülen and the Islamic

Conceptualization of Tolerance". Islam in the Age of Global Challenges Conference Proceedings, 2008.

von der Mehden, Fred R. Islam in Indonesia in the Twenty-First Century, in Asian Islam in the 21 st Century, John L. Esposito John, O. Voll, and Osman Bakar.

Oxford and New York: Oxford University Press, 2008.

Wahid, Abdurrahman. Islamku Islam Anda Islam Kita: Agama Masyarakat Negara Demokrasi, Cet. ke-1. Jakarta: The Wahid Institute, 2006.

Prisma Pemikiran Gus Dur. Yogyakarta: LKiS, 2000. 